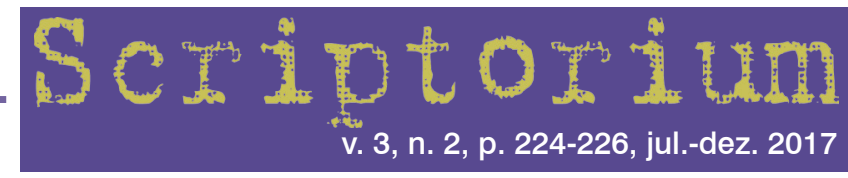

doil" http://dx.doi.org/10.15448/2526-8848.2017.2.30417

\title{
Éramos seis
}

\author{
TALITA JABS EGER* \\ Núcleo de Pesquisa sobre Culturas Contemporâneas (NUPECS/UFRGS), Porto Alegre, RS, Brasil
}

Ontem ainda, suspirava:

"Céu! Somos os condenados da terra!".

ARTHUR RIMBAUD

A gente era tão feliz. Eu, ele, os três filhos já paridos e um ainda por vir.

A gente era tão feliz que nossa felicidade era assunto na vizinhança. A Eni sempre me dizia que um dia ia encontrar um homem bom e trabalhador que nem o meu.

Era verdade, o meu trabalhava muito. De dia. De noite. Catava o que via pela frente, corria pra vender e voltava pra catar mais.

Da rua trazia o pão de cada dia e, às vezes, trazia também umas roupas pra mim e uns brinquedos pras crianças.

Tem gente rica por aí que joga no lixo as coisas que ainda tão nova. Se tem um furinho, nós costura. Se tá manchado... quem vai notar?
E esse negócio de validade também é bobagem, tu não acha?

Pois eu acho que sim. Deve ser pras fábrica venderem mais. Sabe quantas vezes eu morri por causa disso? Nenhuma. É sério, não ri não!

Nossa vida era assim mesmo. Boazinha. Como Deus queria. Homem bom que nem aquele, nunca mais. Trabalhador, nunca ergueu a mão pra mim nem pros menino. Não bebia, não fumava, nem andava por aí tendo assunto com mulher.

Vivia cansado. Tadinho. É porque trabalhava demais. Quando largava a carroça, para dar um descanso pro Agenor - é, é, o cavalo -, andava por aí atrás de bico pra fazer. Pra não deixar faltar nada, sabe. Nunca deixou. A gente não tinha o

\footnotetext{
* Doutoranda em Políticas Públicas pela Universidade Federal do Rio Grande do Sul (UFRGS), mestre em Antropologia Social pela mesma universidade e graduada em Filosofia pela Pontifícia Universidade Católica do Rio Grande do Sul (PUCRS). Vinculada ao Núcleo de Pesquisa sobre Culturas Contemporâneas (NUPECS/UFRGS), ao Núcleo de Pesquisa em Gestão Municipal: capacidades estatais, federalismo e administração municipal para o desenvolvimento na América Latina (NUPEGEM/UFRGS) e integrante do Grupo de Antropologia da Economia e da Política (GAEP/UFRGS). Tem experiência na área de Antropologia, com ênfase em antropologia urbana e econômica e na área de Políticas Públicas, com ênfase em políticas sociais. Dedica-se à análise de políticas de saúde direcionadas ao HIV/Aids, políticas de proteção social e assistência social e capacidades estatais, focando, sobretudo, em populações consideradas vulneráveis.
} 
do bom e do melhor, mas também nunca passamos precisão.

Ele andava feliz da vida porque tava pra chegar mais um guri. Minha barriga mal e mal aparecia, mas ele falava todo o dia com o moleque.

Tu sabe que eu até dizia pra ele que isso era maluquice. Tu tá é falando com as minhas tripa, homem! Ele ria. E continuava cantando e falando pro meu umbigo.

As criança são tudo a cara dele. Cuspido e escarrado. Como é que pode, né?

Além dos dois meninos e da menina, tava chegando mais um machinho. Ele já tinha me deixado avisada "vamo tentar de novo. Quero mais uma guria".

Juntou dinheiro um tempão porque queria comprar uma tevezinha que o Zé ali da esquina tava querendo vender.

Um dia chegou em casa e já foi gritando lá do portão, nem deu tempo da gente chegar lá. Veio correndo com a TV na mão. Pequena, preta e branco, sabe?

Colocou lá no quarto. Que é sala também, que a casa é pequena.

E nós assistia sempre. O jornal, a novela do 12 e quando chegava no filme ele sempre dormia. Tadinho.

Gostava de assistir as coisas com as criança por perto. Deitava um num braço, o outro noutro braço e a guria ficava por cima da barriga dele. Às vezes, quando ele queria me fazer um chamego, me chamava para assistir também e encostava a cabeça na minha barriga.

Ele sonhava demais, sabe?

Queria dar uma vida melhor pras criança. Porque a gente num teve, né. Pra nós tudo foi difícil. Sempre na dureza, desde pequenos.

Daí, deitado na minha barriga, ele disse que nós precisava de uma casa maior, com pátio, pra ter espaço pros bichos e pras crianças...

Ficou quieto um tempão. Já era hora do filme e eu achei que ele tinha dormido. Trabalhava muito. Tadinho.

Mas não. Ele deitou em cima da minha barriga, com as criança encostada nos braços dele e daí não acordou mais. Tu acredita?

Tu não faz ideia de como doeu. Eu ainda choro toda noite, mas não deixo as criança ver.

A gente era tão feliz.

Sem ele ficou difícil cuidar das crianças e mais com guri que tava na barriga.

Começamo a passar fome e necessidade. Eu me entreguei, é verdade. Quase morri. O doutor disse que era depressão, que eu devia fazer um esforço para poder cuidar dos meus filhos que era tudo pequeno e precisavam de mim. Já num tinham o pai.

Mas eu não conseguia. Queria morrer com ele. Nem banho tomava mais. Por que Deus não me levou junto, hein?

Eu pedia pra Deus me levar.

Daí um dia veio uma mulher da igreja, uma crente, sabe?

Achei que era Deus falando comigo. Ela disse que ia me ajudar a melhorar. Eu acreditei.

As crianças e eu tava passando fome. Vivendo tipo bicho. Achei que ela ia ajudar a gente com comida e só.

Deu uma cesta básica. Uns dias depois perguntou se eu queria ajuda para cuidar das crianças. Eu estava há tanto tempo sem comer, tão fraca, tão fraca. Tu lembra como eu era, né?

Daí aceitei. Ela levou minha guria pra casa dela. Nunca mais trouxe de volta, nunca mais me devolveu.

Encontrei ela esses dia na rua, tava com a Vitória do lado. Achei que ela ia gostar 
de ver os irmão dela, que já tavam com os olhos cheio d'água. Tadinhos.

Que nada. Olhou de longe e nem quis dar um beijo neles. Disse que eles fede. E eu também. Agora ela chama a crente de mãe. E eu não.

Ah, eu não vou na polícia, né. Como vou reclamar se ela tava tentando me ajudar, né.
Ah, não. Isso não. Não peço mais ajuda pra ninguém.

Antes a gente era seis. Eu pedi ajuda e agora a gente ficamo só em quatro.

Deus me livre precisar de ajuda de novo. Não posso mais perder ninguém.

Recebido: 15 de novembro de 2017. Aceite: 7 de dezembro de 2017. 